OPEN ACCESS

Edited by:

Paola Angelini,

University of Perugia, Italy

Reviewed by:

Carolina Elena Girometta,

University of Pavia, Italy

Olumayowa M. Olowe,

North-West University, South Africa

Andrea Ceci,

Sapienza University of Rome, Italy

*Correspondence:

Simone Di Piazza

simone.dipiazza@unige.it

Specialty section: This article was submitted to

Fungi-Plant Interactions,

a section of the journal

Frontiers in Fungal Biology

Received: 30 September 2021

Accepted: 27 October 2021

Published: 24 November 2021

Citation:

Cecchi G, Di Piazza S, Rosatto S, Mariotti MG, Roccotiello E and Zotti M

(2021) A Mini-Review on the

Co-growth and Interactions Among Microorganisms (Fungi and Bacteria)

From Rhizosphere of

Metal-Hyperaccumulators.

Front. Fungal Biol. 2:787381.

doi: 10.3389/ffunb.2021.787381

\section{A Mini-Review on the Co-growth and Interactions Among Microorganisms (Fungi and Bacteria) From Rhizosphere of Metal-Hyperaccumulators}

\author{
Grazia Cecchi ${ }^{1}$, Simone Di Piazza ${ }^{1 *}$, Stefano Rosatto ${ }^{2}$, Mauro Giorgio Mariotti $^{2}$, \\ Enrica Roccotiello ${ }^{2}$ and Mirca Zotti ${ }^{1}$ \\ ${ }^{1}$ Laboratory of Mycology, Department of Earth, Environment and Life Sciences, University of Genoa, Genoa, Italy, \\ ${ }^{2}$ Laboratory of Plant Biology, Department of Earth, Environment and Life Sciences, University of Genoa, Genoa, Italy
}

The co-growth and synergistic interactions among fungi and bacteria from the rhizosphere of plants able to hyper accumulate potentially toxic metals (PTMs) are largely unexplored. Fungi and bacteria contribute in an essential way to soil biogeochemical cycles mediating the nutrition, growth development, and health of associated plants at the rhizosphere level. Microbial consortia improve the formation of soil aggregates and soil fertility, producing organic acids and siderophores that increase solubility, mobilization, and consequently the accumulation of nutrients and metals from the rhizosphere. These microorganism consortia can both mitigate the soil conditions promoting plant colonization and increase the performance of hyperaccumulator plants. Indeed, microfungi and bacteria from metalliferous soils or contaminated matrices are commonly metal-tolerant and can play a key role for plants in the phytoextraction or phytostabilization of metals. However, few works deepen the effects of the inoculation of microfungal and bacterial consortia in the rhizosphere of metallophytes and their synergistic activity. This mini-review aimed to collect and report the data regarding the role of microbial consortia and their potentialities known to date. Moreover, our new data had shown an active fungal-bacteria consortium in the rhizosphere of the hyperaccumulator plant Alyssoides utriculata.

Keywords: fungal-bacterial consortia, metallophytes, PTMs removal, rhizobiota, rhizosphere interactions

\section{INTRODUCTION}

Among the non-renewable life-supporting resources, the soil is the main reservoir of potentially toxic metals (PTMs). Many technologies, traditional (chemical-physical-electrical) and not (biological), were developed to decrease the PTMs contamination in soils (Liu et al., 2018). Traditional technologies often have a very negative impact on ecosystems and biodiversity due, for example, to the employment of chemicals or soil excavation (Ali et al., 2013; Lacalle et al., 2020). On the contrary, biological methods are cheap, sustainable, but timeconsuming. For this reason, the real application of these methods to date is limited. To cope with this problem, recently, many studies were carried out to improve the performance of 
biological methods, integrating different biotechnologies (Asad et al., 2019; Alves et al., 2021; Tiodar et al., 2021). For example, phytostrategies benefit from the use of microorganisms, particularly plant growth-promoting bacteria (PGPB) and fungi (PGPF), to remediate contaminated sites (Alves et al., 2021; Tiodar et al., 2021). Microorganisms intervene in biogeochemical cycles, minerals dissolution and/or bioprecipitation, and metals mobilization, and/or immobilizations thanks to their metabolic pathways, organic acids, and enzymes (Choudhary, 2012; Singh and Shourie, 2021). These bio-products can alter the microenvironment in which these microbes live and promote redox and other chemical reactions, also modifying the $\mathrm{pH}$ of the substrates (Singh and Shourie, 2021). Hence many studies were developed to investigate the role played by rhizobiota in plant growth promotion and protection (Hao et al., 2021; Khalid et al., 2021). Most plants are not able to mitigate the impacts of environmental stress, depending on microorganisms (mainly fungi and bacteria) (Singh and Shourie, 2021). Beneficial fungal symbioses (mycorrhization and endophytism) not only can allow plants specific habitats colonization, but also the adaptation to many stresses due to the global climatic change (e.g., increase of carbon dioxide $\left[\mathrm{CO}_{2}\right], \mathrm{UV}$ radiation, and desertification, among others) (Rodriguez and Redman, 2008; Rodriguez et al., 2008; Choudhary, 2012; Cecchi et al., 2019b; Singh and Shourie, 2021). Together with fungi, bacteria are also known to be plant growth promoters (Basu et al., 2021). In the rhizosphere of metallophytes, these microbes can increase the efficiency of phytoremediation of contaminated ecosystems. PTMs-resistantPGPB is characterized by the capability to stabilize PTMs reducing their toxicity through physiological and biochemical activities (Harindintwali et al., 2020).

Recently, some studies assessed the role and interactions among bacteria, fungi, and plants in phytomining, and phytoremediation processes (Thijs et al., 2017; Kazemalilou et al., 2020; Alves et al., 2021). However, many works investigate only the group of mycorrhizal fungi, while the role of microfungi associated with plants root is still little studied (Turnau and Mesjasz-Przybylowicz, 2003; Mishra et al., 2016; Alves et al., 2021). Moreover, the interactions between PGPB and nonmycorrhizal fungi are not clear to date. Few studies deepened these interactions and the possible synergism between bacteria and fungi in the rhizosphere of hyperaccumulator plants (Rosatto et al., 2021a).

This mini-review aimed to briefly collect the data regarding the role of bacteria and microfungi in the rhizosphere of PTMs hyperaccumulator plants, reporting data on the interactions between these microorganisms in the rhizosphere and data on how these relations could influence the rate of metals uptake by plants.

\section{THE ROLE OF BACTERIA IN THE RHIZOSPHERE OF METALLOPHYTES}

To date, the PGP role of rhizosphere bacteria is well-known (Souza et al., 2015; Vejan et al., 2016; Leontidou et al., 2020; Basu et al., 2021). Many in situ studies were carried out on various plants species in order to verify the PTMs tolerance and bioaccumulation by PGPB from the rhizosphere (Han et al., 2020; Ali et al., 2021). They can solubilize and mobilize PTMs increasing their availability, altering the soil $\mathrm{pH}$, and inducing redox reactions through the secretion of biosurfactants, organic acids, siderophore, and chelating agents (Rajkumar et al., 2012; Ojuederie and Babalola, 2017). Moreover, PGPB can produce phytohormones [e.g., auxin and indole3 -acetic acid (IAA)] responsible for regulating plants growth and essential in the adaptation to environmental stresses such as PTMs (Rajkumar et al., 2012; Asad et al., 2019; Wagi and Ahmed, 2019). The majority of PGPB were identified as endophytes from PTM-contaminated soils in plant rhizospheres and tissues. The most frequent genera are Agrobacterium, Bacillus, Brucella, Burkholderia, Escherichia, Mesorhizobium, Pseudomonas, Rhizobium, and Streptomyces. Many authors have shown that coupling bioaugmentation with selected PTMresistant PGPB and phytoremediation technologies can positively affect the PTMs phytoextraction (Harindintwali et al., 2020; Wang et al., 2021). The role played by native microbes is essential: many reports show that bacterial strains collected from ultramafic soils, associated with Ni hyperaccumulators, tolerate higher concentrations of $\mathrm{Ni}$ in comparison to strains from other soils (Turgay et al., 2012; Rosatto et al., 2019). Etesami (2018) evidenced that the inoculation of plants rhizosphere with PTMs resistant strains of PGPB can alleviate plant stress, helping plants to mitigate PTMs toxicity and reducing their accumulation in plant tissues. Kumar et al. (2021), after the isolation of native endophytic bacteria from the tissues of the Ni-hyperaccumulator Odontarrhena obovata C.A. Mey., screened the strains about their $\mathrm{Cu}$ tolerance and PGP function. The authors not only selected a Pseudomonas lurida Behrendt et al. 2007 strain as the most performant in $\mathrm{Cu}$ remediation but also tested this strain in the rhizosphere of sunflower. They evidenced that rhizospheric soil added with the bacterium showed an increase in $\mathrm{Cu}$ uptake by 8.6 -fold for roots and 1.9-fold for leaves than uninoculated plants. Moreover, Khatri et al. (2020) studied Cd tolerance of cold-tolerant and PGP rhizobacteria Pseudomonas putida (Trevisan, 1889) Migula 1895 and Bacillus subtilis, isolated from the Indian Himalaya Region, and their effects on growth and $\mathrm{Cd}$ accumulation in wheat seedlings under mountain ecosystem. They showed that bacteria protect the wheat plants reducing and preventing $\mathrm{Cd}$ bioaccumulation in wheat and the food chain, also improving its growth. Regarding $\mathrm{Ni}$ hyperaccumulator species, a study from 2003 reported that Microbacterium arabinogalactanolyticum (Yokota et al. 1993) Takeuchi and Hatano 1998 has an important role in enhancing Ni availability and therefore its accumulation by Odontarrhena chalcidica (Janka) Španiel, Al-Shehbaz, D.A. German, and Marhold (AbouShanab et al., 2003; Bani and Echevarria, 2019; Rosenkranz et al., 2019; Dimitrakopoulos et al., 2021; Hipfinger et al., 2021). An increase of $32.4 \%$ in shoot $\mathrm{Ni}$ concentration was reported after inoculation, in comparison with the uninoculated specimens. Another study, with the same plant species, but with another bacterial strain inoculated, Microbacterium oxydans (Chatelain and Second 1966) Schumann et al. (1999), also showed an increase in Ni bioaccumulation (Abou-Shanab et al., 2006). Other 
studies showed that the inoculation of Pseudomonas fluorescens complex strongly increases Sedum alfredi Hance biomass, enzyme activities, shoot chlorophyll, and $\mathrm{Cd}$ concentration (Chen et al., 2017) as already demonstrated by Chen et al. (2014) and Ali et al. (2017) for IAA-producing endophytic bacteria. Recent studies reveal that $P$. fluorescens significantly enhances the photosynthetic yield in terms of maximum quantum yield of Photosystem II, photochemical quenching, net photosynthetic rates, intercellular $\mathrm{CO}_{2}$ concentration, transpiration rate, and stomatal conductance (Wu et al., 2020a). Furthermore, $P$. fluorescens promotes the development of lateral roots and the root-to-shoot transport of $\mathrm{Cd}$, improving the phytoremediation efficiency (Wu et al., 2020b,c).

Among endophytes, Streptomyces lydicus De Boer et al. (1956) is known to promote health and plant growth (Worsley et al., 2020), colonizing the root and acting as PGP in pea plant and other legumes (Tokala et al., 2002). However, only certain strains contribute to increasing plant biomass individually and in combination; conversely, other strains appear to inhibit the development of Arabidopsis thaliana (L.) Heynh (Worsley et al., 2020).

\section{THE ROLE OF MICROFUNGI IN THE RHIZOSPHERE OF METALLOPHYTES}

Most of the studies carried out on the role of fungi in the rhizosphere deal with the mycorrhizal fungi (Turnau and Mesjasz-Przybylowicz, 2003; Mishra et al., 2016; Alves et al., 2021) which supply essential nutrients, increase plant health, and enhance stress tolerance (e.g., drought). Fungi can induce the immobilization of metals on the surface of living hyphae using chemical bonding groups in the cell wall or by complexation of the metals with small molecular organic compounds secreted in the rhizosphere (Thijs et al., 2017; Cecchi et al., 2019a). Concerning hyperaccumulator plants, for example, they were thought to be non-mycorrhizal, therefore, there is still little information in comparison to studies on bacterial inoculants (Khan, 2005; Benizri and Kidd, 2018). The first $\mathrm{Ni}$ hyperaccumulator plant in which the presence of arbuscular mycorrhizal fungi was reported was Berkheya coddii Roessler (Turnau and Mesjasz-Przybylowicz, 2003; Alves et al., 2021). Moreover, little is still known about the role of microfungi in the rhizosphere of plants able to hyper accumulate PTMs. These associations of the microorganisms can also modify the chemical composition of root exudates and the bioavailability of PTMs in the soil. Zhang et al. (2018) studied the bioremediation mechanisms of $\mathrm{Pb}$ and $\mathrm{Cd}$ contaminated soil using two indigenous fungi (Mucor circinelloides Tiegh. and Trichoderma asperellum Samuels, Lieckf. and Nirenberg) selected from mine tailings as the phytostimulation of A. thaliana and showed that these microfungi can relieve plant stress improving the phytoremediation activity. Among different Trichoderma species, T. harzianum Rifai represents the highest metabolic diversity which is associated with its numerous beneficial effects on plants such as growth promotion and enhancement of stress resistance (Zeilinger et al., 2016). Many studies evidenced its role in the rhizosphere of plants able to bioaccumulate and hyper accumulate metals, and also its capability to uptake $\mathrm{Ni}, \mathrm{Cu}$, and Ag (Zotti et al., 2014; Roccotiello et al., 2015; Cecchi et al., 2017a,b). Wazny et al. (2021) focused on the role of endophytic fungi in the enhancing of Ni-hyperaccumulation by Noccaea caerulescens (J. Presl and C. Presl) F.K. Mey. After the isolation and identification of fungal strains, they inoculated plants with six fungal species. They reported that Diaporthe columnaris (D.F. Farr and Castl.) Udayanga and Castl. was able to improve $\mathrm{Ni}$ uptake by plants, also activating specific gene networks. Xie et al. (2014) investigated the role of Aspergillus aculeatus Iizuka in the rhizosphere of bermudagrass [Cynodon dactylon (L.) Pers.] a known species able to bioaccumulate $\mathrm{Cd}$. The inoculation of the plants with this fungal strain showed that A. aculeatus improved Cd tolerance and reduced Cd transportation to shoot of bermudagrass. Similarly, Babu et al. (2014) tested Trichoderma sp. and Talaromyces aculeatus (Raper and Fennell) Samson, N. Yilmaz, Frisvad and Seifert strains, isolated from the rhizosphere of Pinus koraiensis Siebold and Zucc. in a mine tailing soil, for their PTMs tolerance and PGP characteristics. They reported that the isolates increased available $\mathrm{P}$ in a 1:1 (w/w) mixture of soil and liquid media by $14-43 \%$ and the bioavailability of $\mathrm{As}, \mathrm{Cu}$, $\mathrm{Pb}$, and $\mathrm{Zn}$, and exhibited phosphatase, phytase, and siderophore activity. In this scenario, Restu and Payangan (2019) studied the production of IAA by some rhizosphere fungal strains. Fusarium resulted in the genus with the highest production of IAA, showing how fungi of this genus could be exploited as biological fertilizers. This result is very interesting because Fusarium is a well-know parasite/pathogen of crops. However, not all the species belonging to this genus show the presence of the pathogenicity gene (i.e., non-pathogenic strains belonging to F. oxysporum, F. solani (Mart.) Sacc. and F. fujikuroi Nirenberg species; Al-Ani, 2019), evidencing how the relations between fungi and plants can be very complex and difficult to understand (Zeilinger et al., 2016). Comparative analyses have revealed that the Fusarium genome is compartmentalized into regions responsible for primary metabolism, reproduction, pathogen virulence, host specialization, and possibly other functions (Ma et al., 2013). Hence there is the possibility to transfer pathogenic chromosomes to non-pathogenic species (horizontal transfer) within the Fusarium genus (Ma et al., 2013).

Other microfungi, isolated from the rhizosphere of the facultative hyperaccumulator A. utriculata, such as Penicillium canescens Sopp, P. ochrochloron, and T. harzianum showed the capability to tolerate Ni (Rosatto et al., 2019). Moreover, the Pikovskaya agar P solubilization test (Firew et al., 2016) and the Chrome Azurol siderophore production test (Milagres et al., 1999) highlighted PGP features (production of halos in the culture media) of the abovementioned species (Figure 1). Among microfungi, yeasts also can be PGP agents, but few works to date investigated their role. Fu et al. (2016) tested their yeast isolates for indole-3-acetic acid-, ammonia-, and polyamine-producing abilities, calcium phosphate and zinc oxide solubilizing ability, catalase activity, siderophore activity, and 1-aminocyclopropane-1-carboxylate deaminase, confirming the essential role that yeasts can play in the rhizosphere of plants. 

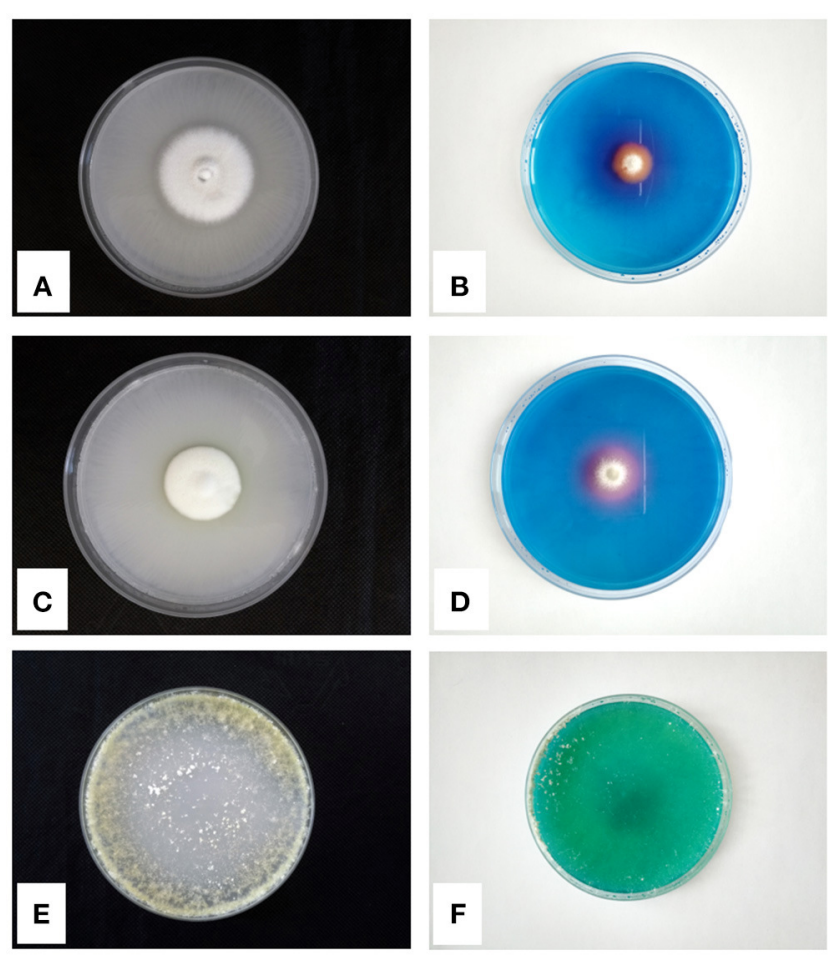

FIGURE 1 | P-solubilization tests on Pikovskaya Agar and siderophores production tests on CAS-Agar of Penicillium ochrochloron (A,B), Penicillium canescens (C,D), and Trichoderma harzianum (E,F), respectively.

\section{INTERACTIONS AMONG MICROFUNGI AND BACTERIA IN THE RHIZOSPHERE OF METALLOPHYTES}

As shown in Table 1, few studies were carried out on the application of microfungi and bacteria in assisted phytoremediation (Jambon et al., 2018; Tiodar et al., 2021). Some researchers investigated the whole rhizospheric and endophytic microbiota, their roles in metal tolerance and transformation (Thijs et al., 2017), the efficiency of PGPB and arbuscular mycorrhizal in phytoremediation and the advantage of the synergistic application of fungi and bacteria (Kazemalilou et al., 2020). However, the fungi-bacteria interactions are complex to investigate (mainly by co-growth tests, culturable methods, or molecular methods such as metagenomic) and not completely understood (Deveau et al., 2018; Rosatto et al., 2021a). This latter can range from negative if, for example, they compete for nutrients; neutral if they do not interact; positive in case of synergistic relationships, for example, when microorganisms increase the nutrient bioavailability through nitrogen fixation and mobilization of key nutrients to the plants (Martin et al., 2017; Nazir et al., 2017; Deveau et al., 2018). For this reason, there is still much to investigate about the interaction between non-mycorrhizal rhizospheric microfungi and bacteria (Rashid et al., 2016). The study of interactions between these microorganisms dates back to the last 20 years, and its possible application to phytoremediation is very recent (Rashid et al., 2016). The synergistic interactions of various beneficial rhizosphere microbes could represent a potential suitable biotechnological tool for a successful phytoremediation process (Guarino and Sciarrillo, 2017). Often the employment of a single methodology of bioremediation is not enough for the total removal of contaminants in the medium and long term. Thanks to the research of new sustainable techniques of remediation, many studies on the selection of metallophytes and hyperaccumulator plants (Afif et al., 2021; Gieroń et al., 2021) have recently led to the investigation of the microbiota of the rhizosphere of these plants, trying to understand the mechanisms of metals tolerance, translocation, uptake, and the possible role played by associated roots microorganisms. In general, rhizosphere microbes of metallophytes and hyperaccumulator plants have been reported for the potential to increase in root surface area for the absorption and recycling of plant nutrients, improve plant health, and control plant pathogens (Figueiredo et al., 2010; Guarino and Sciarrillo, 2017). Guarino and Sciarrillo (2017) applied an integrated approach of bioremediation involving plants, autochthonous endo-ectomycorrhizal fungi, and bacteria. They explained that the inoculated plants showed an increase of biomass and toxic elements accumulation in the root system. To date, it is still questioned whether phytoremediation is attributed to the whole microbiome rather than a single taxon. Deng et al. (2018) tried to understand the role of the whole microbial community of Elsholtzia splendens Nakai ex F.Maek. var. splendens (Sub E. haichowensis Y.Z.Sun), a well-known indicator of $\mathrm{Cu}$, under different environmental factors (EFs). They showed how these EFs can influence or not the microbial populations, giving a hand for understanding the construction of microbial communities in the rhizosphere. De Maria et al. (2011) studied the effect of phytoaugmentation with the rhizobacteria Agromyces sp., Streptomyces sp. and the co-inoculation of each of them with the fungus Hyaloscypha finlandica on biomass production and the bioaccumulation of selected trace elements (zinc $[\mathrm{Zn}]$, cadmium [Cd], and iron $[\mathrm{Fe}]$ ) and macronutrients (calcium [Ca], potassium $[\mathrm{K}]$, phosphorus $[\mathrm{P}]$, and magnesium $[\mathrm{Mg}]$ ) in Salix caprea $\mathrm{L}$. grown on moderately polluted soil. They showed that the bacterial strain belonging to the Streptomyces genus was most efficient to increase the accumulation of $\mathrm{Zn}$ and $\mathrm{Cd}$ in leaves and shoots of $S$. caprea, but also that the combination of $H$. finlandica plus the bacterial strain of Agromyces genus resulted in an enhanced accumulation of $\mathrm{Cd}$ in shoots. Streptomyces is a well-known PGPB strain and the capability to favor the accumulation of the metal by $S$. caprea in the study (De Maria et al., 2011) confirmed it. However, recent investigations on the possible synergistic relations of this bacterium with rhizospheric fungi revealed a small possibility to interact with them. Streptomyces resulted to prefer to be indifferent to fungi or only developing slight positive interactions (Rosatto et al., 2021a). This feature seems to confirm that some strains of Streptomyces show a broad-spectrum antimicrobial activity (Worsley et al., 2020). Indeed, genus Streptomyces is well-known for its ability to synthesize a wide range of bioactive metabolites against bacteria, fungi, plants, insects, nematodes, and viruses 
TABLE 1 | List of the main fungal-bacterial consortia employed for the attenuation of PTM stress and the improvement of phytoremediation efficiency in plants.

\begin{tabular}{llll}
\hline Consortia & Plants & Matrices & References \\
\hline Penicillium ochrochloron Biourge & $\begin{array}{l}\text { Alyssoides utriculata } \\
\text { (L.) Medik. }\end{array}$ & $\begin{array}{l}\text { Soil naturally contaminated } \\
\text { by Ni }\end{array}$ & Rosatto et al., \\
Pseudomonas fluorescens Migula 1895 & Acacia saligna (Labill.) & $\begin{array}{l}\text { Industrial site contaminated } \\
\text { by PTMs }\end{array}$ & $\begin{array}{l}\text { G.KL. Wendl. } \\
\text { Pisolithus arhizus (Scop.) Rauschert }\end{array}$ \\
& & Sciarrillo, 2017
\end{tabular}

Acaulospora colombiana (Spain and N.C. Schenck) H.KL. Wendl. by PTMs

Rhizophagus clarus (T.H. Nicolson and N.C. Schenck)

C. Walker and A. Schüßler

Claroideoglomus etunicatum (W.N. Becker and Gerd.)

C. Walker and A. Schüßler

Rhizophagus intraradices (N.C. Schenck and G.S. Sm.)

C. Walker and A. Schüßler

Bacillus licheniformis (Weigmann 1898) Chester 1901

Priestia megaterium (de Bary 1884) Gupta et al. 2020

Paenibacillus polymyxa (Prazmowski 1880) Ash et al. 1994

Bacillus subtilis (Ehrenberg 1835) Cohn 1872

Bacillus thuringiensis Berliner 1915

Paenibacillus azotofixans (Seldin et al. 1984) Ash et al. 1994

\section{Pisolithus arhizus}

\section{Acaulospora colombiana}

Rhizophagus clarus

Claroideoglomus etunicatum

Rhizophagus intraradices

Bacillus licheniformis

Priestia megaterium

Paenibacillus polymyxa

Bacillus subtilis

Bacillus thuringiensis

Paenibacillus azotofixans

Hyaloscypha finlandica (C.J.K. Wang and H.E. Wilcox)

Vohník, Fehrer, and Réblová

Agromyces sp.

Streptomyces sp.

Paecilomyces formosus Sakag., May. Inoue and Tada ex Houbraken and Samson

Sphingomonas sp.

Glomus sp.

\section{Acaulospora sp.}

Scutellospora sp.

Streptomyces sp.

Azotobacter sp.

Pseudomonas sp.

Paenibacillus sp.

Glomus sp.

Acaulospora sp.

Scutellospora sp.

\section{Eucalyptus}

camaldulensis Dehnh.
Industrial site contaminated

by PTMs
Guarino and Sciarrillo, 2017
Salix caprea L.

Glycine max L.

Cenchrus americanus (L.) Morrone
Experimental soil contaminated by PTMs

Experimental soil contaminated by $\mathrm{Al}$ and $\mathrm{Zn}$

Soil contaminated by Fe
De Maria et al., 2011

Bilal et al., 2018

Mishra et al., 2016
Sorghum bicolor (L.) Moench
Soil contaminated by Fe
Mishra et al., 2016 
TABLE 1 | Continued

\begin{tabular}{|c|c|c|c|}
\hline Consortia & Plants & Matrices & References \\
\hline \multicolumn{4}{|l|}{ Streptomyces sp. } \\
\hline \multicolumn{4}{|l|}{ 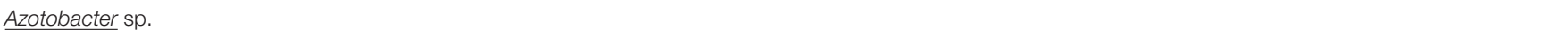 } \\
\hline \multicolumn{4}{|l|}{ Pseudomonas sp. } \\
\hline \multicolumn{4}{|l|}{ Paenibacillus sp. } \\
\hline Acaulospora mellea Spain and N.C. Schenck & $\begin{array}{l}\text { Centrosema coriaceum } \\
\text { Benth. }\end{array}$ & Iron ore deposit & Matias et al., 2009 \\
\hline \multicolumn{4}{|l|}{ Gigaspora margarita W.N. Becker and I.R. Hall } \\
\hline \multicolumn{4}{|c|}{ Dentiscutata heterogama (T.H. Nicolson and Gerd.) } \\
\hline \multicolumn{4}{|l|}{ Glomus sp. } \\
\hline \multicolumn{4}{|l|}{ Fusarium oxysporum Schltdl. } \\
\hline \multicolumn{4}{|l|}{ Aspergillus fischeri Wehmer } \\
\hline \multicolumn{4}{|l|}{ Rhizobium sp. } \\
\hline Acaulospora mellea & $\begin{array}{l}\text { Pleroma heteromallum } \\
\text { (D.Don) D.Don }\end{array}$ & Iron ore deposit & Matias et al., 2009 \\
\hline \multicolumn{4}{|l|}{ Gigaspora margarita } \\
\hline \multicolumn{4}{|l|}{ Dentiscutata heterogama } \\
\hline \multicolumn{4}{|l|}{ Glomus sp. } \\
\hline \multicolumn{4}{|l|}{ Fusarium oxysporum } \\
\hline \multicolumn{4}{|l|}{ Aspergillus fischeri } \\
\hline Rhizobium sp. & & & \\
\hline
\end{tabular}

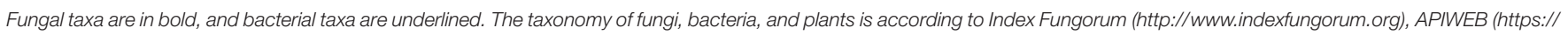
www.biomerieux.it), and Plants of the World Online (http://www.plantsoftheworldonline.org).

(Hasani et al., 2014; Van der Meij et al., 2017; Hutchings et al., 2019).

Another study by Rosatto et al. (2021a,b) was conducted on the root development with respect to metals and possible interactions of bacteria and microfungal strains isolated from the rhizosphere of the facultative hyperaccumulator Alyssoides utriculata, showing how only a few species built positive relations and co-grew with it. The best performing strains in terms of $\mathrm{Ni}$ tolerance and PGP traits were subjected to in vitro tests to establish mutual interactions and identify a clear synergy between the bacterial and the fungal component (Rosatto et al., 2021a). Thanks to their tests, they selected a $P$. fluorescens strain and a Penicillium ochrochloron strain as the most performant. Their synergistic behavior could suggest the potential use of in vivo microorganism consortia to mitigate metal stress and promote metal uptake for bioremediation purposes.

\section{CONCLUSION}

The development of integrated approaches of bioremediation, which involve different synergistic organisms together, is

\section{REFERENCES}

Abou-Shanab, R. A., Angle, J. S., Delorme, T. A., Chaney, R. L., Van Berkum, P., Moawad, H., et al. (2003). Rhizobacterial effects on nickel extraction from soil and uptake by Alyssum the new frontier of bioremediation techniques. Hence, the rhizobiota of metallophytes seems to play a central role as a basin of PGP bacteria and microfungi employable in phytoremediation processes. However, to date, many studies should be carried out to deepen and understand the interactions among roots, bacteria, and microfungi in the tolerance and uptake of PTMs. It has been shown that microorganisms associated with the roots of metallophytes can individually increase the plant biomass of the roots themselves ( $\mathrm{Wu}$ et al., 2020b,c), while there are few studies that demonstrate how both bacteria and microfungi can further increase root biomass together.

\section{AUTHOR CONTRIBUTIONS}

GC, SR, MM, ER, and MZ contributed to conception of the paper and organized the data. GC and SR wrote the first draft of the manuscript. GC, SD, SR, and ER wrote sections of the manuscript. All authors contributed to manuscript revision, read, and approved the submitted version. 
Afif, E., Díaz, T. E., and Gallego, J. L. R. (2021). Screening of pioneer metallophyte plant species with phytoremediation potential at a severely contaminated hg and as mining site. Environments 8:63. doi: 10.3390/environments8070063

Al-Ani, L. K. T. (2019). "Secondary metabolites of non-pathogenic fusarium: scope in agriculture," in Secondary Metabolites of Plant Growth Promoting Rhizomicroorganisms, eds H. Singh, C. Keswani, M. Reddy, E. Sansinenea, and C. García-Estrada (Singapore: Springer), 59-76.

Ali, A., Guo, D., Li, Y., Shaheen, S. M., Wahid, F., Antoniadis, V., et al. (2021). Streptomyces pactum addition to contaminated mining soils improved soil quality and enhanced metals phytoextraction by wheat in a green remediation trial. Chemosphere 273:129692. doi: 10.1016/j.chemosphere.2021.129692

Ali, H., Khan, E., and Sajad, M. A. (2013). Phytoremediation of heavy metals-Concepts and applications. Chemosphere 91, 869-881. doi: 10.1016/j.chemosphere.2013.01.075

Ali, S., Charles, T. C., and Glick, B. R. (2017). "Endophytic phytohormones and their role in plant growth promotion," in Functional Importance of the Plant Microbiome, ed S. Doty (Cham: Springer), 89-105.

Alves, A. R., Oliveira, R. S., Silva, E. F., and Novo, L. A. (2021). "Role of bacteria and mycorrhizal fungi in phytomining: status and future perspectives," in Microbe Mediated Remediation of Environmental Contaminants, eds A. Kumar, V. Kumar Singh, P. Singh, and V. Kumar Mishra (Cambridge: Woodhead Publishing, Elsevier), 15-26.

Asad, S. A., Farooq, M., Afzal, A., and West, H. (2019). Integrated phytobial heavy metal remediation strategies for a sustainable clean environment-a review. Chemosphere 217, 925-941. doi: 10.1016/j.chemosphere.2018.11.021

Babu, A. G., Shim, J., Shea, P. J., and Oh, B. T. (2014). Penicillium aculeatum PDR4 and Trichoderma sp. PDR-16 promote phytoremediation of mine tailing soil and bioenergy production with sorghum-sudangrass. Ecol. Eng. 69, 186-191. doi: 10.1016/j.ecoleng.2014.03.055

Bani, A., and Echevarria, G. (2019). Can organic amendments replace chemical fertilizers in nickel agromining cropping systems in Albania? Int. J. Phytoremediation 21, 43-51. doi: 10.1080/15226514.2018.1523871

Basu, A., Prasad, P., Das, S. N., Kalam, S., Sayyed, R. Z., Reddy, M. S., et al. (2021). Plant growth promoting rhizobacteria (PGPR) as green bioinoculants: recent developments, constraints, and prospects. Sustainability 13:1140. doi: $10.3390 /$ su13031140

Benizri, E., and Kidd, P. S. (2018). "The role of the rhizosphere and microbes associated with hyperaccumulator plants in metal accumulation," in Agromining: Farming for Metals. Mineral Resource Reviews, eds A. Van der Ent, G. Echevarria, A. Baker, and J. Morel (Cham: Springer), 157-188.

Bilal, S., Shahzad, R., Khan, A. L., Kang, S. M., Imran, Q. M., Al-Harrasi, A., et al. (2018). Endophytic microbial consortia of phytohormones-producing fungus Paecilomyces formosus LHL10 and bacteria Sphingomonas sp. LK11 to Glycine $\max \mathrm{L}$. regulates physio-hormonal changes to attenuate aluminium and zinc stresses. Front. Plant Sci. 9:1273. doi: 10.3389/fpls.2018.01273

Cecchi, G., Ceci, A., Marescotti, P., Persiani, A. M., Di Piazza, S., and Zotti, M. (2019a). Interactions among microfungi and pyrite-chalcopyrite mineralizations: tolerance, mineral bioleaching, and metal bioaccumulation. Mycol. Prog. 18, 415-423. doi: 10.1007/s11557-018-01466-y

Cecchi, G., Di Piazza, S., Marescotti, P., and Zotti, M. (2019b). Evidence of pyrite dissolution by Telephora terrestris Ehrh in the Libiola mine (Sestri Levante, Liguria, Italy). Heliyon 5:e02210. doi: 10.1016/j.heliyon.2019.e02210

Cecchi, G., Marescotti, P., Di Piazza, S., and Zotti, M. (2017a). Native fungi as metal remediators: silver myco-accumulation from metal contaminated wasterock dumps (Libiola Mine, Italy). J. Environ. Sci. Health Part B 52, 191-195. doi: 10.1080/03601234.2017.1261549

Cecchi, G., Roccotiello, E., Di Piazza, S., Riggi, A., Mariotti, M. G., and Zotti, M. (2017b). Assessment of Ni accumulation capability by fungi for a possible approach to remove metals from soils and waters. J. Environ. Sci. Health Part B 52, 166-170. doi: 10.1080/03601234.2017.1261539

Chen, B., Luo, S., Wu, Y., Ye, J., Wang, Q., Xu, X., et al. (2017). The effects of the endophytic bacterium Pseudomonas fluorescens Sasm05 and IAA on the plant growth and cadmium uptake of Sedum alfredii Hance. Front. Microbiol. 8:2538. doi: $10.3389 /$ fmicb.2017.02538

Chen, B., Zhang, Y., Rafiq, M. T., Khan, K. Y., Pan, F., Yang, X., et al. (2014). Improvement of cadmium uptake and accumulation in Sedum alfredii by endophytic bacteria Sphingomonas SaMR12: effects on plant growth and root exudates. Chemosphere 117, 367-373. doi: 10.1016/j.chemosphere.2014.07.078
Choudhary, D. K. (2012). Microbial rescue to plant under habitat-imposed abiotic and biotic stresses. Appl. Microbiol. Biotechnol. 96, 1137-1155. doi: 10.1007/s00253-012-4429-x

De Maria, S., Rivelli, A. R., Kuffner, M., Sessitsch, A., Wenzel, W. W., Gorfer, M., et al. (2011). Interactions between accumulation of trace elements and macronutrients in Salix caprea after inoculation with rhizosphere microorganisms. Chemosphere 84, 1256-1261. doi: 10.1016/j.chemosphere.2011.05.002

Deng, S., Ke, T., Li, L., Cai, S., Zhou, Y., Liu, Y., et al. (2018). Impacts of environmental factors on the whole microbial communities in the rhizosphere of a metal-tolerant plant: Elsholtzia haichowensis Sun. Environ. Pollut. 237, 1088-1097. doi: 10.1016/j.envpol.2017.11.037

Deveau, A., Bonito, G., Uehling, J., Paoletti, M., Becker, M., Bindschedler, S., et al. (2018). Bacterial-fungal interactions: ecology, mechanisms and challenges. FEMS Microbiol. Rev. 42, 335-352. doi: 10.1093/femsre/fuy008

Dimitrakopoulos, P. G., Aloupi, M., Tetradis, G., and Adamidis, G. C. (2021). Broomrape species parasitizing Odontarrhena lesbiaca (Brassicaceae) individuals act as nickel hyperaccumulators. Plants 10:816. doi: $10.3390 /$ plants10040816

Etesami, H. (2018). Bacterial mediated alleviation of heavy metal stress and decreased accumulation of metals in plant tissues: mechanisms and future prospects. Ecotoxicol. Environ. Saf. 147, 175-191. doi: 10.1016/j.ecoenv.2017.08.032

Figueiredo, M. D. V. B., Seldin, L., de Araujo, F. F., and Mariano, R. D. L. R. (2010). "Plant growth promoting rhizobacteria: fundamentals and applications," in Plant Growth and Health Promoting Bacteria, ed D. Maheshwari (Springer, Berlin, Heidelberg), 21-43.

Firew, E., Delelegn, W., and Diriba, M. (2016). Phosphate solubilization potential of rhizosphere fungi isolated from plants in Jimma zone, southwest Ethiopia. Int. J. Microbiol. 2016:5472601. doi: 10.1155/2016/5472601

Fu, S. F., Sun, P. F., Lu, H. Y., Wei, J. Y., Xiao, H. S., Fang, W. T., et al. (2016). Plant growth-promoting traits of yeasts isolated from the phyllosphere and rhizosphere of Drosera spatulata Lab. Fungal Biol. 120, 433-448. doi: 10.1016/j.funbio.2015.12.006

Gieroń, Z., Sitko, K., Zieleznik-Rusinowska, P., Szopiński, M., Rojek-Jelonek, M., Rostański, A., et al. (2021). Ecophysiology of Arabidopsis arenosa, a new hyperaccumulator of $\mathrm{Cd}$ and $\mathrm{Zn}$. J. Hazard. Mater. 412:125052. doi: 10.1016/j.jhazmat.2021.125052

Guarino, C., and Sciarrillo, R. (2017). Effectiveness of in situ application of an Integrated Phytoremediation System (IPS) by adding a selected blend of rhizosphere microbes to heavily multi-contaminated soils. Ecol. Eng. 99, 70-82. doi: 10.1016/j.ecoleng.2016.11.051

Han, H., Wu, X., Yao, L., and Chen, Z. (2020). Heavy metal-immobilizing bacteria combined with calcium polypeptides reduced the uptake of $\mathrm{Cd}$ in wheat and shifted the rhizosphere bacterial communities. Environ. Pollut. 267:115432. doi: 10.1016/j.envpol.2020.115432

Hao, L., Zhang, Z., Hao, B., Diao, F., Zhang, J., Bao, Z., et al. (2021). Arbuscular mycorrhizal fungi alter microbiome structure of rhizosphere soil to enhance maize tolerance to La. Ecotoxicol. Environ. Saf. 212:111996. doi: 10.1016/j.ecoenv.2021.111996

Harindintwali, J. D., Zhou, J., Yang, W., Gu, Q., and Yu, X. (2020). Biocharbacteria-plant partnerships: eco-solutions for tackling heavy metal pollution. Ecotoxicol. Environ. Saf. 204:111020. doi: 10.1016/j.ecoenv.2020.111020

Hasani, A., Kariminik, A., and Issazadeh, K. (2014). Streptomycetes: characteristics and their antimicrobial activities. Int. J. Adv. Biol. Biomed. Res. 2, 63-75.

Hipfinger, C., Rosenkranz, T., Thüringer, J., and Puschenreiter, M. (2021). Fertilization regimes affecting nickel phytomining efficiency on a serpentine soil in the temperate climate zone. Int. J. Phytoremediation 23, 407-414. doi: $10.1080 / 15226514.2020 .1820446$

Hutchings, M. I., Truman, A. W., and Wilkinson, B. (2019). Antibiotics: past, present and future. Curr. Opin. Microbiol. 51, 72-80. doi: 10.1016/j.mib.2019.10.008

Jambon, I., Thijs, S., Weyens, N., and Vangronsveld, J. (2018). Harnessing plantbacteria-fungi interactions to improve plant growth and degradation of organic pollutants. J. Plant Interact. 13, 119-130. doi: 10.1080/17429145.2018.144 1450

Kazemalilou, S., Delangiz, N., Lajayer, B. A., and Ghorbanpour, M. (2020). "Insight into plant-bacteria-fungi interactions to improve plant performance 
via remediation of heavy metals: an overview," in Molecular Aspects of Plant Beneficial Microbes in Agriculture, eds V. Sharma Richa and S. Laith Tawfeeq (Amsterdam: Elsevier), 123-132.

Khalid, M., Saeed, U. R., Hassani, D., Hayat, K., Pei, Z. H. O. U., and Nan, H. U. I. (2021). Advances in fungal-assisted phytoremediation of heavy metals: a review. Pedosphere 31, 475-495. doi: 10.1016/S1002-0160(20)60091-1

Khan, A. G. (2005). Role of soil microbes in the rhizospheres of plants growing on trace metal contaminated soils in phytoremediation. J. Trace Elements Med. Biol. 18, 355-364. doi: 10.1016/j.jtemb.2005.02.006

Khatri, S., Sharma, R. K., and Shridhar, V. (2020). Influence of cadmium-tolerant and plant growth-promoting rhizobacteria on cadmium accumulation and growth response of wheat seedlings under mountain ecosystem. Agric. Res. 9, 56-65. doi: 10.1007/s40003-019-00407-9

Kumar, A., Voropaeva, O., Maleva, M., Panikovskaya, K., Borisova, G., Rajkumar, M., et al. (2021). Bioaugmentation with copper tolerant endophyte Pseudomonas lurida strain EOO26 for improved plant growth and copper phytoremediation by Helianthus annuus. Chemosphere 266:128983. doi: 10.1016/j.chemosphere.2020.128983

Lacalle, R. G., Becerril, J. M., and Garbisu, C. (2020). Biological methods of polluted soil remediation for an effective economically-optimal recovery of soil health and ecosystem services. J. Environ. Sci. Public Health 4,112-133. doi: 10.26502/jesph.96120089

Leontidou, K., Genitsaris, S., Papadopoulou, A., Kamou, N., Bosmali, I., Matsi, T., et al. (2020). Plant growth promoting rhizobacteria isolated from halophytes and drought-tolerant plants: genomic characterisation and exploration of phyto-beneficial traits. Sci. Rep. 10, 1-15. doi: 10.1038/s41598-020-71652-0

Liu, L., Li, W., Song, W., and Guo, M. (2018). Remediation techniques for heavy metal-contaminated soils: principles and applicability. Sci. Total Environ. 633, 206-219. doi: 10.1016/j.scitotenv.2018.03.161

Ma, L. J., Geiser, D. M., Proctor, R. H., Rooney, A. P., O’Donnell, K., Trail, F., et al. (2013). Fusarium pathogenomics. Annu. Rev. Microbiol. 67, 399-416. doi: 10.1146/annurev-micro-092412-155650

Martin, F. M., Uroz, S., and Barker, D. G. (2017). Ancestral alliances: plant mutualistic symbioses with fungi and bacteria. Science 356:eaad4501. doi: 10.1126/science.aad4501

Matias, S. R., Pagano, M. C., Muzzi, F. C., Oliveira, C. A., Carneiro, A. A., Horta, S. N., et al. (2009). Effect of rhizobia, mycorrhizal fungi and phosphate-solubilizing microorganisms in the rhizosphere of native plants used to recover an iron ore area in Brazil. Eur. J. Soil Biol. 45, 259-266. doi: 10.1016/j.ejsobi.2009.02.003

Milagres, A. M., Machuca, A., and Napoleao, D. (1999). Detection of siderophore production from several fungi and bacteria by a modification of chrome azurol S (CAS) agar plate assay. J. Microbiol. Methods 37, 1-6. doi: 10.1016/S0167-7012(99)00028-7

Mishra, V., Gupta, A., Kaur, P., Singh, S., Singh, N., Gehlot, P., et al. (2016). Synergistic effects of Arbuscular mycorrhizal fungi and plant growth promoting rhizobacteria in bioremediation of iron contaminated soils. Int. J. Phytoremediation 18, 697-703. doi: 10.1080/15226514.2015.1131231

Nazir, R., Mazurier, S., Yang, P., Lemanceau, P., and van Elsas, J. D. (2017). The ecological role of type three secretion systems in the interaction of bacteria with fungi in soil and related habitats is diverse and context-dependent. Front. Microbiol. 8:38. doi: 10.3389/fmicb.2017.00038

Ojuederie, O. B., and Babalola, O. O. (2017). Microbial and plant-assisted bioremediation of heavy metal polluted environments: a review. Int. J. Environ. Res. Public Health 14:1504. doi: 10.3390/ijerph14121504

Rajkumar, M., Sandhya, S., Prasad, M. N. V., and Freitas, H. (2012). Perspectives of plant-associated microbes in heavy metal phytoremediation. Biotechnol. Adv. 30, 1562-1574. doi: 10.1016/j.biotechadv.2012.04.011

Rashid, M. I., Mujawar, L. H., Shahzad, T., Almeelbi, T., Ismail, I. M., and Oves, M. (2016). Bacteria and fungi can contribute to nutrients bioavailability and aggregate formation in degraded soils. Microbiol. Res. 183, 26-41. doi: 10.1016/j.micres.2015.11.007

Restu, A. M., and Payangan, R. Y. (2019). Production of IAA (Indole Acetic Acid) of the rhizosphere fungus in the Suren community forest stand. IOP Conf. Ser. Earth Environ. Sci. 343:012058. doi: 10.1088/1755-1315/343/1/012058

Roccotiello, E., Marescotti, P., Di Piazza, S., Cecchi, G., Mariotti, M. G., and Zotti, M. (2015). "Biodiversity in metal-contaminated sites-problem and perspective-a case study," in Biodiversity in Ecosystems-Linking Structure and Function, ed J. A. Blanco (London: IntechOpen), 581-600.

Rodriguez, R., and Redman, R. (2008). More than 400 million years of evolution and some plants still can't make it on their own: plant stress tolerance via fungal symbiosis. J. Exp. Bot. 59, 1109-1114. doi: 10.1093/jxb/erm342

Rodriguez, R. J., Henson, J., Van Volkenburgh, E., Hoy, M., Wright, L., Beckwith, F., et al. (2008). Stress tolerance in plants via habitat-adapted symbiosis. ISME J. 2, 404-416. doi: 10.1038/ismej.2007.106

Rosatto, S., Cecchi, G., Roccotiello, E., Di Piazza, S., Di Cesare, A., Mariotti, M. G., et al. (2021a). Frenemies: interactions between Rhizospheric Bacteria and Fungi from Metalliferous Soils. Life 11:273. doi: 10.3390/life11040273

Rosatto, S., Mariotti, M., Romeo, S., and Roccotiello, E. (2021b). Root and shoot response to nickel in hyperaccumulator and non-hyperaccumulator species. Plants 10:508. doi: 10.3390/plants10030508

Rosatto, S., Roccotiello, E., Di Piazza, S., Cecchi, G., Greco, G., Zotti, M., et al. (2019). Rhizosphere response to nickel in a facultative hyperaccumulator. Chemosphere 232, 243-253. doi: 10.1016/j.chemosphere.2019.05.193

Rosenkranz, T., Hipfinger, C., Ridard, C., and Puschenreiter, M. (2019). A nickel phytomining field trial using Odontarrhena chalcidica and Noccaea goesingensis on an Austrian serpentine soil. J. Environ. Manage. 242, 522-528. doi: 10.1016/j.jenvman.2019.04.073

Singh, A., and Shourie, A. (2021). "Climate change impacts on plant-microbe interactions," in Climate Change and the Microbiome. Soil Biology, vol 63, eds D. K. Choudhary, A. Mishra, and A. Varma (Cham: Springer), 155-186.

Souza, R. D., Ambrosini, A., and Passaglia, L. M. (2015). Plant growth-promoting bacteria as inoculants in agricultural soils. Genet. Mol. Biol. 38, 401-419. doi: 10.1590/S1415-475738420150053

Thijs, S., Langill, T., and Vangronsveld, J. (2017). The bacterial and fungal microbiota of hyperaccumulator plants: small organisms, large influence. $A d v$. Bot. Res. 83, 43-86. doi: 10.1016/bs.abr.2016.12.003

Tiodar, E. D., Văcar, C. L., and Podar, D. (2021). Phytoremediation and microorganisms-assisted phytoremediation of mercury-contaminated soils: challenges and perspectives. Int. J. Environ. Res. Public Health 18:2435. doi: 10.3390/ijerph18052435

Tokala, R. K., Strap, J. L., Jung, C. M., Crawford, D. L., Salove, M. H., Deobald, L. A., et al. (2002). Novel plant-microbe rhizosphere interaction involving Streptomyces lydicus WYEC108 and the pea plant (Pisum sativum). Appl. Environ. Microbiol. 68, 2161-2171. doi: 10.1128/AEM.68.5.2161-2171.2002

Turgay, O. C., Görmez, A., and Bilen, S. (2012). Isolation and characterization of metal resistant-tolerant rhizosphere bacteria from the serpentine soils in Turkey. Environ. Monit. Assess. 184, 515-526. doi: 10.1007/s10661-0111984-z

Turnau, K., and Mesjasz-Przybylowicz, J. (2003). Arbuscular mycorrhiza of Berkheya coddii and other Ni-hyperaccumulating members of Asteraceae from ultramafic soils in South Africa. Mycorrhiza 13, 185-190. doi: 10.1007/s00572-002-0213-6

Van der Meij, A., Worsley, S. F., Hutchings, M. I., and van Wezel, G. P. (2017). Chemical ecology of antibiotic production by actinomycetes. FEMS Microbiol. Rev. 41, 392-416. doi: 10.1093/femsre/fux005

Vejan, P., Abdullah, R., Khadiran, T., Ismail, S., and Nasrulhaq Boyce, A. (2016). Role of plant growth promoting rhizobacteria in agricultural sustainability-a review. Molecules 21:573. doi: 10.3390/molecules 210 50573

Wagi, S., and Ahmed, A. (2019). Bacillus spp.: potent microfactories of bacterial IAA. PeerJ 7:e7258. doi: 10.7717/peerj.7258

Wang, G., Zhang, Q., Du, W., Ai, F., Yin, Y., Ji, R., et al. (2021). Microbial communities in the rhizosphere of different willow genotypes affect phytoremediation potential in Cd contaminated soil. Sci. Total Environ. 769:145224. doi: 10.1016/j.scitotenv.2021.145224

Wazny, R., Rozpadek, P., Domka, A., Jedrzejczyk, R. J., Nosek, M., HubalewskaMazgaj, M., et al. (2021). The effect of endophytic fungi on growth and nickel accumulation in Noccaea hyperaccumulators. Sci. Total Environ. 768:144666. doi: 10.1016/j.scitotenv.2020.144666

Worsley, S. F., Newitt, J., Rassbach, J., Batey, S. F., Holmes, N. A., Murrell, J. C., et al. (2020). Streptomyces endophytes promote host health and enhance growth across plant species. Appl. Environ. Microbiol. 86:e01053-e01020. doi: 10.1128/AEM.01053-20 
Wu, Y., Ma, L., Liu, Q., Sikder, M. M., Vestergård, M., Zhou, K., et al. (2020a). Pseudomonas fluorescens promote photosynthesis, carbon fixation and cadmium phytoremediation of hyperaccumulator. Sedum alfredii. Sci. Total Environ. 726:138554. doi: 10.1016/j.scitotenv.2020.138554

Wu, Y., Ma, L., Liu, Q., Topalovi,ć, O., Wang, Q., Yang, X., et al. (2020b), Pseudomonas fluorescens accelerates a reverse and long-distance transport of cadmium and sucrose in the hyperaccumulator plant. Sedum alfredii. Chemosphere 256:127156. doi: 10.1016/j.chemosphere.2020.127156

Wu, Y., Ma, L., Liu, Q., Vestergård, M., Topalovic, O., Wang, Q., et al. (2020c). The plant-growth promoting bacteria promote cadmium uptake by inducing a hormonal crosstalk and lateral root formation in a hyperaccumulator plant. Sedum alfredii. J. Hazard. Mater. 395:122661. doi: 10.1016/j.jhazmat.2020.122661

Xie, Y., Luo, H., Du, Z., Hu, L., and Fu, J. (2014). Identification of cadmiumresistant fungi related to $\mathrm{Cd}$ transportation in bermudagrass [Cynodon dactylon (L.) Pers.]. Chemosphere 117, 786-792. doi: 10.1016/j.chemosphere.2014. 10.037

Zeilinger, S., Gupta, V. K., Dahms, T. E., Silva, R. N., Singh, H. B., Upadhyay, R. S., et al. (2016). Friends or foes? emerging insights from fungal interactions with plants. FEMS Microbiol. Rev. 40, 182-207. doi: 10.1093/femsre/fuv045

Zhang, X., Li, X., Yang, H., and Cui, Z. (2018). Biochemical mechanism of phytoremediation process of lead and cadmium pollution with Mucor circinelloides and Trichoderma asperellum. Ecotoxicol. Environ. Saf. 157, 21-28. doi: 10.1016/j.ecoenv.2018.03.047
Zotti, M., Di Piazza, S., Roccotiello, E., Lucchetti, G., Mariotti, M. G., and Marescotti, P. (2014). Microfungi in highly copper-contaminated soils from an abandoned $\mathrm{Fe}-\mathrm{Cu}$ sulphide mine: growth responses, tolerance and bioaccumulation. Chemosphere 117, 471-476. doi: 10.1016/j.chemosphere.2014.08.057

Conflict of Interest: The authors declare that the research was conducted in the absence of any commercial or financial relationships that could be construed as a potential conflict of interest.

Publisher's Note: All claims expressed in this article are solely those of the authors and do not necessarily represent those of their affiliated organizations, or those of the publisher, the editors and the reviewers. Any product that may be evaluated in this article, or claim that may be made by its manufacturer, is not guaranteed or endorsed by the publisher.

Copyright $\odot 2021$ Cecchi, Di Piazza, Rosatto, Mariotti, Roccotiello and Zotti. This is an open-access article distributed under the terms of the Creative Commons Attribution License (CC BY). The use, distribution or reproduction in other forums is permitted, provided the original author(s) and the copyright owner(s) are credited and that the original publication in this journal is cited, in accordance with accepted academic practice. No use, distribution or reproduction is permitted which does not comply with these terms. 